\title{
Hubungan Koping Spiritual dengan Post Stroke Depression pada Pasien Stroke Iskemik setelah Tiga Bulan Serangan
}

\author{
Fitria Handayani ${ }^{1}$ \\ ${ }^{1}$ Departemen Ilmu Keperawatan Fakultas Kedokteran, Universitas Diponegoro, Semarang, Indonesia \\ fitriaha@yahoo.co.id
}

\begin{abstract}
Background: The prevalence of Post Stroke Depression (PSD) among ischemic stroke survivor after three months onset is high. PSD is influenced by biological, psychological, and social factors. Spiritual coping was correlated with good mood among chronic illness patient. However, correlation study between spiritual and PSD was not exist. The aim of the study was to examine the correlation between spiritual coping and PSD among ischemic stroke survivor after three months onset.

Method: The design of the study was correlational design. There were 68 respondents involved. The inclusion criteria were ischemic stroke after three months onset, no aphasia, no hearing impairment, and the total score of Mini Mental Status Examination (MMSE) was more than 12. The tools were HAMD-GRID 17 (PSD) and Spiritual Coping Questionaire (SCQ). Validation language conducted in two cycles and the test reliability used alpha cronbach (.776). Ethical approval was conducted by ethical committee of Medicine Faculty. The data collection used was survey. The statistical analyze used the Spearman-rho.

Results: The results of the study show that demographic characteristic were equal between male and female. The age ranged 51 to 60 was 42.6\%, unemployment patient was $61.8 \%$, and the income less than $R p$ 1,000,000 was $63.2 \%$. Statistical analyses showed that no correlation between spiritual and PSD ( $r-.155, p .205)$.

Discussion: Spiritual transformation process is a complex process and diverse among social situation. Transformation in spiritual responses should be gained in advance study to identify the developing of PSD.
\end{abstract}

Keywords: Post Stroke Depression, Spiritual Coping.

\begin{abstract}
Abstrak
Pendahuluan: Prevalensi Post Stroke Depression (PSD) pasien stroke iskemik setelah tiga bulan serangan masih tinggi. PSD dipengaruhi oleh faktor biologi, psikologi, dan sosial. Koping spiritual berhubungan dengan mood pasien kronik. Penelitian tentang hubungan spiritual dan PSD pada populasi pasien stoke iskemik setelah tiga bulan serangan belum diteliti. Tujuan adalah mengetahui hubungan antara koping spiritual dan PSD pada pasien stroke iskemik setelah tiga bulan serangan.
\end{abstract}


Metode: Desain penelitian ini adalah penelitian korelasi. Responden berjumlah 68 pasien stroke iskemik. Kriteria inklusi adalah stroke iskemik setelah tiga bulan serangan, tidak afasia, dan mampu mendengar, dan skor Mini Mental Status Examination (MMSE) lebih dari 12. Kuesioner yang digunakan adalah HAM-GRIG 17 (PSD) dan Spiritual Coping Questionnaire (SCQ). Validasi bahasa dilakukan dengan menggunakan dua siklus dan tes reliabilitas menggunakan alpha cronbach dengan hasil HAMD-GRID 17 sebesar 0,776. Persetujuan etik didapat dari komite etik Fakultas Kedokteran Universitas Diponegoro. Pengambilan data menggunakan metode survei. Analisa statistik menggunakan Spearmanrho.

Hasil: Hasil penelitian menunjukkan bahwa karakteristik pasien stroke iskemik setelah tiga bulan serangan pada jenis kelamin memiliki frekuensi yang hampir sama antara laki laki dan perempuan, umur pada rentang 51 dan 60 tahun yaitu 42,6\%, tidak bekerja 61,8\%, penghasilan kurang Rp 1.000.000,- adalah 63,2\%. Hasil korelasi menunjukkan tidak ada hubungan antara koping spiritual dan PSD $(r-0,155, p$ 0,205). Proses transformasi spiritual merupakan hal yang komplek dan berbeda-beda dalam berbagai situasi sosial. Transformasi spiritual sebagai respon perubahan yang mempengaruhi perkembangan PSD perlu diteliti lebih jauh lagi.

Kata kunci: Koping Spiritual, Post Stroke Depression

\section{PENDAHULUAN}

Depresi adalah masalah yang sering terjadi setelah serangan stroke. Pada pasien stroke iskemik, pola Post Stroke Depression (PSD) meningkat pada tiga bulan setelah serangan dan akan menetap hingga enam bulan setelah serangan (Gbiri, Akinpelu, \& Odole, 2010). Prevalensi PSD setelah tiga bulan serangan bervariasi, yaitu 31,6\% berisiko PSD (McCarthy et al., 2016), 27.3 (Li et al., 2014) dan 33,5 merupakan PSD berat (Cheng et al., 2014), dan 47,4 adalah PSD (Kim et al., 2011). PSD berdampak pada kelemahan setelah 1,5 tahun paska serangan (Lerdal et al., 2011), PSD yang berkelanjutan dan pemikiran untuk mengakhiri hidup (Lang \& Borgwardt, 2013), rendahnya kualitas hidup setelah 5 tahun paska stroke (Kielbergerova et al., 2015), dan stroke berulang (Yuan et al., 2012). Lebih jauh lagi, pasien stroke yang mengalami PSD 4,4 kali risiko kematian dari pada pasien stroke tanpa PSD (Naess, Lunde, Brogger, \& Waje-Andreassen, 2010).

Prevalensi PSD yang tinggi pada pasien stroke iskemik setelah tiga bulan serangan berkaitan dengan faktor psikososial, dan biologi. Beberapa penelitian menyebutkan bahwa tingginya prevalensi berhubungan dengan gangguan kognitif, penurunan status fungsional, dan masalah psikososial (Husseini et al., 2017). Faktor biologi berhubungan dengan dengan lokasi lesi, inflamasi, dan perubahan factor neurotropik, gangguan proyeksi cortico-striato-pallido-thalamiccortical, dan perubahan jalur dopamine (Feng, Fang, \& Liu, 2014). Penelusuran sistematik menunjukkan bahwa PSD setelah tiga bulan serangan, berhubungan usia muda, rendahnya dukungan sosial yang diterima, koping, menurunnya kecepatan kognitif, rendahnya memori verbal, hipertensi, kecacatan saat tiga bulan setelah serangan, lesi hemisfer kiri, dan 
Brain Derived Neurotrophin Factor (BDNF) saat masuk rumah sakit (Handayani \& Pudjonarko, 2015).

Spiritual merupakan aspek humanisme yang bertumpu pada cara seseorang dalam mencari arti dan tujuan dengan hubungan dengan kejadian, diri sendiri, orang lain, alam, pengalaman yang berarti atau rasa takut. Penelitian koping spiritual berhubungan dengan kesehatan. Penelitian yang dilakukan di Cina menjelaskan bahwa koping spiritual berkorelasi dengan depresi dan kualitas hidup pada pasien lanjut usia (Moon \& Kim, 2013). Hubungan antara koping spiritual dan depresi pada pasien stroke iskemik setelah serangan belum diteliti. Penelitian ini bertujuan untuk mencari hubungan antara spiritual dan PSD pada paisne stroke iskemik setelah tiga bulan serangan.

\section{METODE}

Desain penelitian adalah descriptive correlational cross-sectional. Peneliti telah melakukan skrining terhadap 120 pasien stroke pada bulan Februari hingga Mei 2018. Responden pada penelitian ini adalah 68 pasien stroke iskemik setelah tiga bulan serangan. Perekrutan sampel dilakukan di Rumah Sakit Tugurejo Semarang dan Kanjeng Raden Mas Tumenggung Wongsonegoro (KRMT) Kota Semarang, Indonesia. Partisipan adalah pasien stroke iskemik yang didiagnosa Dokter dengan mengacu pada AHA 2013 (Sacco et al., 2013). Kriteria inklusi adalah berusia 18-80 tahun, berkunjung ke rumah sakit setelah tiga bulan serangan, tidak afasia, dapat mendengar dan skor Mini Mental Status Examination (MMSE) lebih dari 12. Pasien akan dikeluarkan dari proses penelitian bila mengalami transformasi ke stroke hemoragik. Aspek etik legal dikeluarkan oleh Rumah Sakit Tugurejo Semarang dan komite etik Fakultas Kedokteran Universitas Diponegoro. Responden yang teridentifikasi dalam kriteria inklusi direkrut dan mendapatkan penjelasan serta menandatangani lembar informed consent. Pengukuran

Pengukuran PSD menggunakan GRIDHAMD 17 yang terdiri dari 17 pertanyaan (Williams et al., 2005). Data koping spiritual menggunakan Spiritual Coping Questionnaire (SCQ) yang terdiri dari 32 pertanyaan (Charzyńska, 2015). Validasi Bahasa telah dilakukan ke Bahasa Indonesia dan dilanjutkan dengan Face validity. Tes reliability GRID-HAMD 17 pada pasien stroke iskemik dilakukan dengan Alpha Cronbach, $\mathrm{r}=0,766$. Kuesioner juga telah dilakukan observasi inter-ratter observation between two observers dengan nilai Kappa 0,001. Proses pengambilan data menggunakan metode survei.

Data demografi responden seperti umur, jenis kelamin, penghasilan dan pendidikan disajikan dalam frekuensi. Homogenitas data GRID-HAMD dan spiritualitas menggunakan Saphiro-Wilk. Hubungan antara spirital dan PSD menggunakan Spearman-rho. Tingkat signifikasi ditetapkan pada $\rho<0,05$. Penelitian ini telah lulus uji etik dari komite etik yaitu No: 596/EC/FKRSDK/X/2017.

HASIL

Tabel 1. Karakteristik Responden

\begin{tabular}{lll}
\hline Karakteristik & & $\boldsymbol{f}(\boldsymbol{\%})$ \\
\hline Umur & $<40$ & $2(2,9)$ \\
& $40-50$ & $12(17,6)$ \\
& $51-60$ & $29(42,6)$ \\
& $>60$ & $25(36,8)$ \\
\hline Pendidikan & SD & $42(61,8)$ \\
& SMP & $9(13,2)$ \\
\hline
\end{tabular}




\begin{tabular}{lll}
\hline Karakteristik & & $\boldsymbol{f}(\boldsymbol{\%})$ \\
\hline Pendidikan & SMA & $9(13,2)$ \\
& Diploma/Sar & $5(7,4)$ \\
& jana & $4(4,4)$ \\
& Lain-Lain & \\
\hline Jenis Kelamin & Laki-Laki & $35(51,5)$ \\
& Perempuan & $33(48,5)$ \\
\hline Pekerjaan & Karyawan & $6(8,8)$ \\
& Wiraswasta & $6(8,8)$ \\
& PNS & $9(13,2)$ \\
& TNI/POLRI & $1(1,5)$ \\
& Buruh & $4(5,9)$ \\
& Tidak & $42(61,8)$ \\
& Bekerja & \\
\hline Hasil & $<1$ jt & $43(63,2)$ \\
& 1-3 Juta & $24(35,3)$ \\
& $>3$ juta & $1(1,5)$ \\
\hline
\end{tabular}

Tabel 2. Hubungan antara Koping Spiritual dan PSD

\begin{tabular}{lll}
\hline Variabel & SD (Min-Max) & \\
\cline { 1 - 2 } Spiritual & $\pm 14(83-154)$ & $r-.155^{*}$ \\
\cline { 1 - 2 } PSD & $\pm 7(0-23)$ & $p .205^{*}$
\end{tabular}

Uji Spearman*

Hasil penelitian menunjukkan bahwa karakteristik pasien stroke iskemik setelah tiga bulan serangan memiliki frekuensi yang hampir sama antara laki laki dan perempuan pada jenis kelamin. Umur responden paling banyak berkisar pada 51 dan 60 tahun yaitu 42,6\%. Partisipan sebagian besar tidak bekerja $(61,8 \%)$. Penghasilan partisipan sebagian besar kurang dari 1 juta rupiah sebesar 63,2\%. Hasil korelasi menunjukkan tidak ada hubungan antara koping spiritual dan PSD $(r-.155$ dan $p$.205)

\section{PEMBAHASAN}

Hasil penelitian ini bertentangan dengan hasil peneitian The Brain Attack Surveillance in Corpus Christi (BASIC) di Amerika. Penelitian menunjukkan bahwa pada populasi keturunan Meksiko memiliki spiritual yang baik dan memiliki tingkat depresi yang rendah. Sedangkan pada keturunan non-Hispanic memiliki spiritual yang rendah dan memiliki tingkat depresi yang tinggi (Skolarus et al., 2012). Pada penelitian lain juga menyebutkan bahwa spiritual dan religious berhubungan dengan kualitas hidup pasien gagal ginjal kronik yang menjalani hemodialisa di Saudi Arabia (Saffari et al., 2013). Lebih jauh lagi, spiritual dalam mencintai terhadap sesama, kekuatan yang lebih tinggi, pandangan positif terhadap wawasan dunia berhubungan dengan kesehatan yang lebih baik dan konsisten dengan mode kesehatan psychoneuroimmunological (Campbell, Yoon, \& Johnstone, 2010).

Penelitian ini tidak menunjukkan adanya hubungan antara koping spiritual dan PSD. Koping spiritual memerlukan kaitan antara psikologi dan fisik dan mengaitkannya dengan harapan, kekuatan dalam diri, dan perilaku dalam beradaptasi dalam aktifitas sehari-hari, penggunaan alat bantu dan lingkungan yang baru (The Joanna Briggs Institute, 2010). Peneitian tentang kehidupan pasien setelah serangan stroke menunjukkan bahwa pasien stroke seperti hidup dalam bayangan abu abu dan menjadi pribadi yang berbeda dari sebelumnya (Kouwenhoven, Kirkevold, Engedal, \& Kim, 2012). Penelitian tersebut menunjukkan bahwa kehidupan pasien setelah serangan stroke merupakan kondisi yang komplek yang mencakup antara psikologi dan fisik. Hasil systematic review menjelaskan bahwa proses transformasi kehilangan adalah proses menyatunya seseorang dengan akibat stroke itu sendiri. Proses transformasi koping spiritual merupakan hal yang komplek dan berbedabeda dalam berbagai situasi sosial (Chow \& Nelson-Becker, 2010). Keterlibatan situasi sosial dan budaya perlu diperhatikan pada munculnya depresi. 
Transformasi koping spiritual sebagai respon perubahan yang terjadi setelah serangan perlu diteliti lebih jauh lagi.

Kelemahan penelitian ini adalah tidak menyertakan faktor lain yang menyebabkan depresi. Kelebihan penelitian ini adalah menggambarkan estimasi yang baik hubungan antara koping spiritual dan PSD pada pasien stroke iskemik setelah tiga bulan serangan.

\section{KESIMPULAN DAN SARAN}

Peneliti menyimpulkan tidak ada hubungan antara koping spiritual dan Post Stroke Derpession pada pasien stroke iskemik setelah tiga bulan serangan. Post Stroke Depression dapat dipengaruhi oleh faktor lain. Proses transformasi koping spiritual merupakan hal yang komplek dan berbeda-beda dalam berbagai situasi sosial. Keterlibatan situasi sosial dan budaya perlu diperhatikan pada munculnya depresi. Transformasi koping spiritual sebagai respon perubahan yang terjadi setelah serangan perlu diteliti lebih jauh lagi. Faktor lain yang dapat mempengaruhi PSD perlu diteliti lebih jauh lagi.

\section{DAFTAR PUSTAKA}

Campbell, J. D., Yoon, D. P., \& Johnstone, B. (2010). Determining relationships between physical health and spiritual experience, religious practices, and congregational support in a heterogeneous medical sample. Journal of Religion and Health, 49(1), 3-17. doi: 10.1007/s10943-008-927-5

Cheng, S., Zhao, Y., Li, J., Chen, X., Wang, R., \& Zeng, J. (2014). Plasma levels of glutamate during stroke is associated with development of poststroke depression.
Psychoneuroendocrinology, 47(183), 126-135. doi: 10.1016/j.psyneuen.2014.05.006

Chow, E. O. W., \& Nelson-Becker, H. (2010). Spiritual distress to spiritual transformation: Stroke survivor narratives from Hong Kong. Journal of Aging Studies, 24(4), 313-324. doi: 10.1016/j.jaging.2010.06.001

Lang, U. E., \& Borgwardt, S. (2013). Molecular mechanisms of depression: Perspectives on new treatment strategies. Cell Physiol Biochem, 31(6), 761-777. doi: $10.1159 / 000350094$

Feng, C., Fang, M., \& Liu, X. (2014). The Neurobiological Pathogenesis of Poststroke Depression. The Scientific World Journal, 2014.

Gbiri, C. a, Akinpelu, a O., \& Odole, a C. (2010). Prevalence, pattern and impact of depression on quality of life of stroke survivors. International Journal of Psychiatry in Clinical Practice, 14(March), 198-203.

Handayani, F., \& Pudjonarko, D. (2015). Associated factor and Predictor of Post Stroke Depression after 3 month onset: A Literature Review. 3rd Java International Nursing Conference. semarang.

Husseini, N. El, Hackett, M. L., Jorge, R. E., Kissela, B. M., Mitchell, P. H., Skolarus, L. E., ... Williams, L. S. (2017). AHA/SA Scientific statement poststroke depression. Stroke, 48, 3043. doi: 10.1161/STR.0000000000000113

Kielbergerova, L., Mayer, O.-J., Vanak, J., Bruthans, J., Wohlfahrt, P., \& Ciffkova, R. (2015). Quality of life 
predictors in chronic stable post-stroke patients and prognostic value of SF-36 score as a mortality surrogate. Translational Stroke Research, 6(5), 375-383. doi: 10.1007/s12975-0150418-6

Kim, J.-T., Park, M.-S., Yoon, G.-J., Jung, H.-J., Choi, K.-H., Nam, T.-S., ... Cho, K.-H. (2011). White matter hyperintensity as a factor associated with delayed mood disorders in patients with acute ischemic stroke. European Neurology, 66(6), 343-349. doi: 10.1159/000332585

Kouwenhoven, S. E., Kirkevold, M., Engedal, K., \& Kim, H. S. (2012). "Living a life in shades of grey": Experiencing depressive symptoms in the acute phase after stroke. Journal of Advanced Nursing, 68(8), 17261737. doi: 10.1111/j.13652648.2011.05855.x

Lerdal, A., Bakken, L. N., Rasmussen, E. F., Beiermann, C., Ryen, S., Pynten, S., ... Kim, H. S. (2011). Physical impairment, depressive symptoms and pre-stroke fatigue are related to fatigue in the acute phase after stroke. Disability and Rehabilitation, 33(4), 334-342. doi: $10.3109 / 09638288.2010 .490867$

Li, J., Zhao, Y., Zeng, J., Chen, X., Wang, R., \& Cheng, S. (2014). Serum Brainderived neurotrophic factor levels in post-stroke depression. Journal of Affective Disorders, 168, 373-379. doi: 10.1016/j.jad.2014.07.011

McCarthy, M. J., Sucharew, H. J., Alwell, K., Moomaw, C. J., Woo, D., Flaherty, M. L., ... Kissela, B. M. (2016). Age, subjective stress, and depression after ischemic stroke.
Journal of Behavioral Medicine, 39(1), 55-64. doi: 10.1007/s10865015-9663-0

Moon, Y. S., \& Kim, D. H. (2013). Association between religiosity/spirituality and quality of life or depression among living-alone elderly in a South Korean city. AsiaPacific Psychiatry, 5(4), 293-300. doi: 10.1111/appy.12025

Charzyńska, E. (20015). Multidimensional Approach Toward Spiritual Coping : Construction and Validation of the Spiritual Coping. Journal of Religion and Health, 54(5), 1629-1646. doi: 10.1007/s10943-014-9892-5

Naess, H., Lunde, L., Brogger, J., \& WajeAndreassen, U. (2010). Depression predicts unfavourable functional outcome and higher mortality in stroke patients: The Bergen stroke study. Acta Neurologica Scandinavica, 122(SUPPL. 190), 3438. doi: 10.1111/j.16000404.2010.01373.x

Sacco, R. L., Kasner, S. E., Broderick, J. P., Caplan, L. R., Connors, J. J., Culebras, A., ... Vinters, H. V. (2013). An updated definition of stroke for the 21st century: A statement for healthcare professionals from the American heart association/American stroke association. Stroke, 44(7), 2064-2089. doi: 10.1161/STR.0b013e318296aeca

Saffari, M., Pakpour, A. H., Naderi, M. K., Koenig, H. G., Baldacchino, D. R., \& Piper, C. N. (2013). Spiritual coping, religiosity and quality of life: A study on Muslim patients undergoing haemodialysis. Nephrology, 18(4), 269-275. doi: 10.1111/nep.12041 
Skolarus, L. E., Lisabeth, L. D., Sánchez, B. N., Smith, M. a, Garcia, N. M., Risser, J. M. H., \& Morgenstern, L. B. (2012). The prevalence of spirituality, optimism, depression, and fatalism in a bi-ethnic stroke population. Journal of Religion and Health, 51(4), 12931305. doi: 10.1007/s10943-010-94384

The Joanna Briggs Institute. (2010). The Joanna Briggs Institute best practice information sheet: The psychosocial and spiritual experiences of elderly individuals recovering from a stroke. Nursing and Health Sciences, 12(4), 515-518. doi: 10.1111/j.14422018.2010.00555.x

Williams, J. B. W., Kobak, K. A., Bech, P., Engelhardt, N., Evans, K., Lipsitz, J., ... Pearson, J. (2005). The GRIDHAMD: Standardization of the Hamilton Depression Rating Scale. Inernational Clinical Psychopharmachology, 23(3), 120129. doi: 10.1097/YIC.0b013e3282f948f5

Yuan, H. W., Wang, C. X., Zhang, N., Bai, Y., Shi, Y. Z., Zhou, Y., ... Wang, Y. J. (2012). Poststroke depression and risk of recurrent stroke at 1 year in a Chinese cohort study. PLOS ONE, 7(10), e46906. doi: 10.1371/journal.pone.004690 